\title{
Аналіз функціонування системи відновлення озброєння та військової техніки
}

\author{
Iгор Овчаренко 1 А; Андрій Звонко 2 В; Антон Ткаченко 3 А; \\ Олександр Ярошенко ${ }^{4}$ А \\ А Національний університет оборони України імені Івана Черняховського, м. Київ, Україна

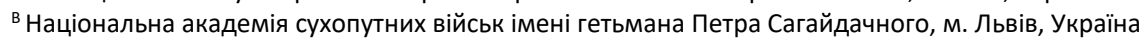

Received: August 15, 2021 | Revised: August 24, 2021 | Accepted: August 31, 2021

DOI: $10.33445 /$ sds.2021.11.4.16

\begin{abstract}
Анотація
Особливості ведення війн та збройних конфліктів вказують на те, що для забезпечення живучості військових формувань, які приймають участь в операціях (бойових діях), одним із пріоритетів є своєчасне повернення до строю пошкоджених зразків озброєння та військової техніки. Успіх виконання завдань під час ведення збройного протистояння в значній мірі буде залежати не тільки від вогневих і ударних можливостей угруповань військ (сил), але і від того, як швидко вони зможуть відновити свою боєздатність в умовах впливу сучасних засобів ураження. Завдання щодо своєчасного відновлення озброєння та військової техніки, в ході ведення операцій (бойових дій) покладається на ремонтно-відновлювальні органи від яких залежить рівень укомплектованості військ (сил) справними зразками озброєння та військової техніки.

В стапті проведено аналіз умов та факторів, які впливали на систему відновлення озброєння та військової техніки в широкомасштабних операціях у Другій Світовій Війні та в локальних війнах в Афганістані, в операції російських військ в Першій Чеченській кампанії. Розкриті основні проблеми з якими стикались ремонтно-відновлювальні підрозділи та частини під час відновлення озброєння та військової техніки в цих війнах та локальних збройних конфліктах 3 метою визначення характерних проблемних питань, що призводять до зниження рівня боєздатності військ.
\end{abstract}

Ключові слова: відновлення озброєння та військової техніки, ремонтно-відновлювальні органи, ремонт, евакуація, технічна розвідка.

\section{Постановка проблеми}

Боєздатність Збройних Сил України, ефективність їх застосування за призначенням вирішальною мірою залежить від рівня їх забезпеченості озброєнням та військовою технікою (ОВТ), матеріальнотехнічними засобами (МТ3), боєприпасами, тощо. У сучасних умовах ведення бойових дій (операцій) провідні країни світу зосереджують свою увагу на пошуку нових методів та способів, які 6 дозволили покращити функціонування системи забезпечення своїх військ, як в цілому, так і за їх ключовими підсистемами. Серед них особливе місце займає система логістичного забезпечення, однією із функцій якої $\epsilon$ відновлення ОВТ. Одним із їі головних завдань $€$ підтримання високого рівня боєздатності військ за рахунок своєчасного та якісного відновлення ОВТ. Під системою відновлення ОВТ розуміється сукупність взаємопов'язаних рухомих і стаціонарних засобів, призначених для проведення технічної розвідки, евакуації і ремонту ОВТ та органів управління ними, об'єднаних

\footnotetext{
${ }^{1}$ Corresponding author: кандидат технічних наук, доцент, професор кафедри, e-mail: i-v-o@ukr.net, ORCID: 0000-0001-9066-0800

2 кандидат технічних наук, доцент, доцент кафедри, e-mail: zvonko2008@ukr.net, ORCID: 0000-0002-7410-799X

${ }^{3}$ кандидат технічних наук, старший науковий співробітник, начальник наукового відділу, e-mail: i-v-o@ukr.net, ORCID: 0000-0002-1620-4206

${ }^{4}$ старший викладач кафедри, e-mail: kss2014@ukr.net, ORCID: 0000-0001-9497-2262
} 
спільною метою, які функціонують за єдиним задумом 3 метою підтримання бойової готовності ОВТ [1].

Розвиток ОВТ на сучасному етапі призвів до зміни форм і способів застосування військ (сил). Але ці зміни призводять до зміни збільшення виконання завдань підрозділами забезпечення, тобто потреби в підвищенні виробничих можливостей підрозділів забезпечення, які відновлюють ОВТ з експлуатаційними або бойовими пошкодженнями.
Для визначення шляхів удосконалення системи відновлення необхідно проаналізувати досвід, який був отриманий військами (силами) в минулих війнах та збройних конфліктах сучасності. Використання даного досвіду надасть можливість врахувати недоліки та переваги у функціонуванні системи відновлення ОВТ в минулих війнах для удосконалення існуючої системи відновлення ОВТ.

\section{Аналіз останніх досліджень та публікацій}

Дослідженню проблем відновлення ОВТ присвячена ціла низка робіт, так, в робіт [2] проведено аналіз виконання завдань військовими частинами (підрозділами) в локальних війнах, збройних конфліктах під час виконання завдань у Міжнародних операціях з підтримання миру і безпеки, про те у даній роботі не розглядаються питання відновлення ОВТ під час виконання завдань за призначенням, а у роботах $[3,4]$ проводиться аналіз відновлення ОВТ військових частин (підрозділів) під час висування та виконання завдань за призначенням, але в даних роботах розглядаються лише питання щодо забезпечення військових частин (підрозділів) боєприпасами, МТЗ при цьому не розглядаються питання щодо функціонування системи відновлення ОВТ і наскільки вона залежить від системи забезпечення МТ3. В роботі [5] розглядається вплив зовнішніх і внутрішніх чинників на організацію відновлення ОВТ підрозділів, але не враховуються тенденції зміни у формах і способах застосування військ (сил), при цьому у роботі [6] проводиться аналіз розвитку форм і способів збройної боротьби, але дана робота не враховує, як буде функціонувати система забезпечення, а саме відновлення. Так в роботі [7] проведений аналіз системи технічного забезпечення в Другій світовій війні, але не розглядаються питання, як впливає забезпеченість ремонтно-відновлювальних органів на проведення ремонту ОВТ, в роботі [8] досліджуються питання технічного забезпечення $3 \mathrm{C}$ Російської Федерації у Чеченській республіці, але у даній роботі не розглядаються питання щодо удосконалення системи відновлення, в роботі [9] на основі аналізу виконання завдань підрозділами забезпечення в локальних війнах та збройних конфліктах та враховуючи досвід виконання завдань військовими частинами (підрозділами) на території Донецької та Луганської областей запропоновано алгоритм функціонування перспективної системи логістичного забезпечення.

\section{Постановка завдання}

Основною характерною рисою використання ремонтно-відновлювальних підрозділів, які застосовувались в операціях бойових діях XX-XXI ст., $\epsilon$ те що вони усі $\epsilon$ послідовниками Радянської системи забезпечення військ (сил) та мають одні принципи (підходи) до виконання завдань
Мета статті полягає у проведенні аналізу функціонування системи відновлення ОВТ у війнах та збройних конфліктах XX-XXI ст., визначення позитивних та негативних чинників, які впливали на її функціонування та визначення перспективних напрямків ії удосконалення. 


\section{Виклад основного матеріалу}

Багатогранність і багатофункціональність процесів системи відновлення обумовлює складність виконання завдань під час бойових дій і його актуальність в сучасних умовах, що вимагає дослідження процесів відновлення ОВТ з наукової точки зору.

У роки Другої світової війни організація технічного обслуговування бойових броньованих машин (ББМ), їх своєчасний ремонт і евакуація були однією 3 найважливіших проблем в загальній сумі заходів щодо забезпечення бойової готовності бронетанкових військ.

Значення цих питань визначалося в першу чергу тим, що поповнення танкових військ новою бойовою технікою в складі маршових підрозділів (підрозділи, які формувалися після закінчення навчання особового складу в навчальних і запасних частинах і з'єднаннях, навчальних центрах i на полігонах) здійснювалося головним чином в ході підготовки до операції, або в період тривалих оперативних пауз.

В ході бойових дій ремонт бойових броньованих машин (ББМ) спеціалістами із заводів промисловості був явищем вкрай рідкісним, винятковим. Тому відновлення пошкоджених зразків озброєння і техніки (ОВТ) в ході бойових дій і швидке їх повернення в підрозділи було найбільш істотним, а часом і єдиним джерелом поповнення втрат у танках. Ремонт танків в ході операцій підвищував боєздатність частин і з'єднань, збільшував силу і глибину танкових ударів і тим самим сприяв успішному виконанню поставлених завдань.

у багатьох випадках, кількість відремонтованих танків і самохідних артилерійських установок у два-три рази перевищувала число ББМ, що були у танковій армії до початку операції. Іншими словами, протягом однієї операції кожен танк виходив з ладу два-три рази і стільки ж разів знову повертався В бойові порядки частин i з'єднань. Так, з досвіду роботи ремонтних органів 3-ї гвардійської танкової армії в період Львівсько-Сандомирської операції (липень-серпень 1944 року) кількість відремонтованих танків в 3 рази перевищувала склад танкового парку, що був у військах армії до початку операції.

Напередодні Другої світової війни Червона Армія не мала достатньої кількості рухомих засобів ремонту, здатних забезпечити своєчасне відновлення пошкоджених ОВТ в ході бою (операції). 3 наявних РВО значну частину становили стаціонарні ремонтні бази і гарнізонні автобронетанкові майстерні, які ремонтували в основному, автомобілі та трактори. Технологія ремонту була примітивна і не забезпечувала належної продуктивності робіт. Більшість таких баз і майстерень дислокувалися в районах, які потрапляли під загрозу окупації. Про те, незабаром після початку бойових дій майже усі вони були евакуйовані і тому в перші місяці війни надати допомогу частинам у відновленні танків не могли.

Брак евакуаційних засобів або погана організація їх роботи часто призводили до збільшення безповоротних втрат у ОВТ. Танки, що зупинилися на полі бою із-за отриманих бойових ушкоджень або під час застрягання на болотистій місцевості, не завжди своєчасно евакуювалися з поля бою. Так, в період з 22 червня по 1 липня 1941 року в 22-му механізованому корпусі вийшли 3 ладу 119 танків. 3 них 58 так і залишилися на полі бою через неможливість їх евакуювати.

В результаті прийнятих заходів до середини 1942 роки було сформовано значну кількість пересувних ремонтних баз (ПРБ), окремих ремонтно-відновних батальйонів, а також частин і підрозділів з евакуації БТОТ. А до літа 1943 року бронетанкові війська мали цілком сформовану організаційно-штатну структуру ремонтних і евакуаційних засобів. У танкових полках і окремих батальйонах були взводи технічного забезпечення (вТх3). Танкові бригади мали в розпорядженні роти технічного забезпечення (РТх3). У штат танкових армій були введені окремі танкоремонтні батальйони (ОТРБ) і по дві евакуаційні роти. Разом з цим, В 
загальновійськових арміях, що мали у своєму складі танкові і самохідно-артилерійські полки, як правило, було по одній пересувній танкоремонтній базі (ПРТБ) і евакуаційній роті. У кінці 1944 року для ударних армій створюються пересувні армійські ремонтноевакуаційні бази (ПАРЕБ), що об'єднували підрозділи ремонту і евакуації. Якщо загальновійськові армії не мали штатних ремонтних частин, то за наявності в їх складі танкових частин вони посилювалися за рахунок фронтових засобів $[10,11]$.

Включення ремонтних підрозділів в штати частин і з'єднань значною мірою сприяло прискоренню ремонту ОВТ, що вийшла 3 ладу.

Під час ведення радянськими військами бойових дій в Афганістані система відновлення ОВТ також вимагала покращення. Проблеми посилювалися відсутністю в Афганістані матеріальнотехнічної бази, необхідної для задоволення потреб військ 40-ої армії. Відновлення ОВТ з'єднань і частин здійснювалося безпосередньо 3 території Радянського Союзу. В період бойових дій в усіх ланках для відновлення ОВТ створювалися тимчасові формування - ремонтно-евакуаційні групи (РЕГ), які комплектувались при підготовці до проведення операцій за рахунок сил і засобів ремонтних підрозділів і частин. Нижчою ланкою, де комплектувалися РЕГ, були мотострілкові і танкові роти. Їх функції покладалися на 2-3 бойові машини, на яких розміщувалися жорсткі буксири, запасні частини, запаси палива і води.

Головним завданням РЕГ роти була евакуація - буксирування несправної або застряглої техніки. У мотострілковому батальйоні (мсб) і танковому батальйоні (тб) в РЕГ входило штатне відділення технічного обслуговування з майстерною МТО. Іноді РЕГ батальйону посилювалася фахівцями 3 ремонтної роти полку. У завдання РЕГ батальйону входило надання допомоги екіпажам при проведенні технічного обслуговування, евакуація несправної i застряглої техніки, поточний ремонт ОВТ із заміною вузлів і деталей. РЕГ батальйону знаходилася безпосередньо за своїми бойовими підрозділами.

У полку створювалася РЕГ комплексного складу, у яку входили: для БТОТ 1-2 відділення з танкоремонтними майстернями TPM- 75, для автомобільної техніки звичайне одне відділення 3 майстерною МРС, для артилерійського озброєння - ремонтне відділення з майстерною МРС-АР. РЕГ полку знаходилась за колоною тилу полку.

у з'єднаннях залежно від масштабу і району бойових дій створювалися одна - дві РЕГ. У будь-якому разі РЕГ з'єднання мала комплексний склад сил і засобів для відновлення усіх основних зразків ОВТ, які застосовувались у бойових діях. її основне завдання полягало у буксируванні несправної техніки до місць ремонту під охорону бойових підрозділів і поточний ремонт.

При підготовці великих тривалих операцій у ряді випадків створювалися армійські комплексні РЕГ у складі ремонтних взводів БМП і БТР, автомобілів і артилерії, ремонтних відділень танків, 2-3 танкових тягачів, 2-3 автомобільних тягачів, 1-2 трейлерів, автомобілів із запасами МТЗ. Такі РЕГ йшли за колоною усього угрупування військ, яке виводилося. Основне завдання РВО транспортних колон полягало у евакуації автомобільної техніки до найближчого гарнізону, пункту технічної допомоги. Штатні пункти технічної допомоги розгорталися на відповідальних маршрутах руху колон. Ці пункти були оснащені комплектом рухомої майстерні ПАРМ- 1.

У армійській ланці була 4904 армійська ремонтно-відновлювальна база (АРВБ), у складі якої були три окремі ремонтновідновні батальйони, окремий евакуаційний батальйон, рота спеціальних робіт, метрологічна лабораторія.

Окремий ремонтно-відновний батальйон бронетанкової техніки (орвб БТТ) здійснював ремонт бронетанкової техніки із заміною основних агрегатів. Його виробничі 
можливості дозволяли проводити капітальний ремонт двигунів і інших агрегатів. За добу проводився ремонт восьми двигунів при нормі п'ять, що дозволяло мати оборотний фонд до 60 відремонтованих двигунів.

Окремий ремонтно-відновний батальйон (орвб) ракетно-артилерійського озброєння (РAO) на стаціонарній базі приступив до роботи тільки з 1986 року. На розгорнутій базі були обладнані ділянки для ремонту легкої і важкої стрілецької зброї. Проводився комплексний ремонт САУ "Гвоздики" i "Акації", гаубиці Д-30 і мінометів.

501 окремий евакуаційний батальйон (оеб) мав у своєму складі дві роти. Для забезпечення роботи використовувалась кожна можливість перекидання запасів запчастин, матеріалів і іншого майна 3 перевалочних баз у війська на тягачах 501 оеб, які вивільнялися після доставки пошкодженої техніки на збірні пункти пошкоджених машин (ЗППМ), які розгортались по сусідству із базою. Крім того цей же транспорт іноді використовувався для завантаження боєприпасів. У організаційноштатній структурі мсп і тп була ремонтна рота. Вона забезпечувала проведення технічних оглядів і виконувала поточний ремонт ОВТ в районах дислокації і при веденні бойових дій. Частина ії сил і засобів виділялася для надання допомоги екіпажам і водіям на заставах і постах. Робота ремонтних рот у бригадах здійснювалася аналогічно полковим.

Важливе значення для оперативного відновлення пошкодженого ОВТ відіграли створені в 1987 році обмінні пункти агрегатів (ОПА). Ці позаштатні формування, як правило, знаходилися при орвб з'єднань, ремонтних ротах полків. Безпосередньо на них здійснювався обмін несправних вузлів і агрегатів на нові або капітально відремонтовані. Створення таких пунктів скорочувало, а у ряді випадків виключало поїздки за вузлами і агрегатами на значно віддалені бази і склади. Наявність ОПА швидко і позитивно було оцінено у військах $[12,13]$.

Характер і особливості організації операції по локалізації конфлікту в Чеченській Республіці наклали свій відбиток на організацію управління відновленням ОВТ військ (сил).

Аналіз отриманого досвіду в першій Чеченській кампанії (1994) свідчить про певні закономірності розвитку

системи відновлення ОВТ, ефективність функціонування, якої багато в чому залежала від узгодженості дій сил і засобів ремонтновідновлювальних підрозділів, що залучалися від Міністерства оборони (МО), інших силових структур та центральних органів виконавчої влади Російської Федерації.

Так, для організації відновлення ОВТ була створена оперативна група Центру (ОГЦ), основу якої склав штаб озброєння Сухопутних військ (СВ), представники головних управлінь Міністерства оборони (МО), як відповідні служби забезпечення зі своїми органами MT3. В оперативну групу Центру було включено представників органів управлінь озброєнням МО, Міністерства Внутрішніх Справ (MBC) і ФСБ. Безпосереднє управління силами і засобами системи відновлення Об'єднаного угруповання військ здійснювалося управлінням озброєння Північнокавказького військового округу (ПКВО) на чолі із заступником командувача військами округу з озброєння, а на напрямках бойових дій - заступниками командирів армійських корпусів з озброєння. На початковому етапі бойових дій до складу ОГЦ входили перші заступники начальників головних управлінь, наділені відповідними повноваженнями.

Таким чином, особливістю управління системою відновлення ОВТ 3 досвіду підготовки операції в Чеченській Республіці стало формування єдиного органу управління відновленням ОВТ різнорідних і різновідомчих угруповань військ (сил), що на практиці наочно показало доцільність створення такого органу з підпорядкуванням 
йому штабу озброєння військового округу, а також відповідних служб і органів.

Для керівництва Тх3 Об'єднаного угруповання військ (ОУВ) безпосередньо на напрямках бойових дій були створені оперативні групи (ОГ) управління відновленням ОВТ на які покладалися такі завдання: оцінка забезпеченості та стану ОВТ і ВТМ; укомплектування підрозділів відновлення ОВТ фахівцями-ремонтниками; організація роботи з ремонту ОВТ, які прибувають для доукомплектування з'єднань і частин.

Управління відновленням ОВТ військ (сил) здійснювалося з тилового пункту управління (ТПУ) ОУВ, а також з ТПУ з'єднань і частин, що брали участь в операції.

Така система органів управління відновленням ОВТ в основному забезпечила оперативне i якісне керівництво угрупованням сил і засобів системи відновлення.

Але виникли проблеми, пов'язані 3 дублюванням функцій ремонту і постачання системи відновлення ЗС РФ, інших військ, військових формувань і органів, що послужило згодом передумовою для розроблення пропозицій по створенню міжвідомчої (об'єднаної) уніфікованої системи (МОУС).

Пропозиції по створенню МОУС ОУВ в ході ведення бойових дій були обумовлені низкою причин, а саме:

- на території Чеченської Республіки в бойових діях спільно брали участь з'єднання і частини МО РФ, внутрішні війська (ВB) МВС, ФСБ Росії, для чого в інтересах досягнення мети відновлення ОВТ ОУВ необхідно було постійно узгоджувати дії органів системи відновлення усіх залучених сил.

- через ОГ відновлення ОВТ заступники командирів підрозділів з озброєння мали вихід безпосередньо на головні управління замовника МО РФ, що дозволяло оперативно вирішувати виникаючі питання з'єднань і частин.

При експлуатації ОВТ доводилося стикатися з несправностями, не пов'язаними з бойовими ушкодженнями. Так, більшість відмов виникала через те, що техніка, якою укомплектовувалися з'єднання і частини, які брали участь у бойових діях, незадовго до цього була знята зі зберігання. При цьому, значна кількість експлуатаційних відмов була обумовлена саме низькою якістю зберігання і невисоким рівнем підготовки фахівців. Особливо це позначалося на якості утримання і готовності автотранспорту, що в свою чергу призводило до передчасного виходу техніки з ладу. При поставці ОВТ в підрозділи техніка доукомплектовувалася витратними матеріалами і ЗІП, які потім доводилося доставляти в райони бойових дій з центральних баз і складів, що значно збільшувало час підготовки ОВТ до використання і відновлення при пошкодженнях.

Рівень підготовки екіпажів не забезпечував належної оперативності у виконанні комплексу заходів по експлуатації ОВT. Відсутність встановленого порядку забезпечення угруповання внутрішніх військ MBC, прикордонних військ при їх спільні дії 3 частинами МО вимагало додаткових витрат матеріальних ресурсів з боку МО РФ [14].

Організація підтримання справності ОВТ полягала у перевірці технічного стану та підготовці їх до бойового застосування 3 обов'язковим проведенням всього комплексу технічного обслуговування; в доукомплектуванні майном згідно табельної потреби; дозаправці ПММ і завантаженні боєприпасами; в підготовці ремонтних і евакуаційних засобів.

Крім обов'язкових заходів для підтримання справного (працездатного) стану на маршрутах руху колон створювалися пункти технічної допомоги, поєднані 3 диспетчерсько-контрольними пунктами, які надавали допомогу водіям в перевірці стану і обслуговуванні машин, поточному ремонті автомобілів, підготовці до евакуації і самої евакуації пошкодженої на марші військової техніки та організації ії тимчасового 
зберігання.

У бойових умовах обслуговування ОВТ не проводилося і зводилося в основному лише до дозаправлення ПММ і дозавантаження боєкомплекту.

Для своєчасного відновлення пошкоджених та несправних зразків ОВТ було створено угруповання сил (засобів) відновлення ОВТ, які складались з ремонтновідновлювальних органів (РВО) з'єднань і частин, складів з боєприпасами та МТЗ, ЗППМ і ремонтно-евакуаційних груп (РЕГ). Додатково були задіяні арсенали і бази Центру МО РФ. Крім цього, для здійснення складного ремонту ОВТ залучалися бригади фахівців від ремонтних підприємств.

Виходячи із завдань військ (сил) для посилення угруповання сил (засобів) системи відновлення було прийнято рішення сформувати зведені ремонтновідновлювальні батальйони (рвб) на основі армійських і корпусних ремонтновідновлювальних баз [15].

Важливим принципом організації ремонту $\epsilon$ автономність кожного підрозділу, який відновлював ОВТ в ході ведення бойових дій у відриві від головних сил. Але з огляду на постійну можливість нападу противника, проведення ним диверсійних дій, відновлення бойової техніки проводилося не на марші і не в місцях їі виходу з ладу, а на ЗППМ або в пунктах дислокації.

Особливе місце при відновленні ОВТ приділялось технічній розвідці. При цьому інформація про технічну обстановку збиралася, аналізувалася і передавалася до вищих органів управління. Найбільш ефективним способом технічної розвідки було її ведення з повітря (з вертольотів).

Для технічної розвідки в районах бойових дій створювалися групи технічної розвідки (ГР). В їх завдання входило: визначення місць розташування пошкоджених зразків ОВТ, визначення стану екіпажів, водіїв, встановлення причин і характеру пошкоджень ОВТ; орієнтовна оцінка обсягу відновлювальних робіт, пошук шляхів, зручних для переміщення евакуаційних засобів до пошкоджених зразків ОВТ, уточнення шляхів евакуації [16].

Визначалися також місцезнаходження та можливості використання трофейних зразків ОВТ та технічного майна, велася інженерна розвідка шляхів евакуації, районів розміщення ремонтних і евакуаційних сил і засобів та шляхів їх переміщення.

Особливості технічної розвідки полягали в наступному:

- технічна розвідка велася тільки в світлий час доби, практично під постійним впливом противника, тому їі тривалість була обмежена;

- маршрути висування ГТР періодично мінялися;

- 3 поля бою спочатку евакуйовували поранених і загиблих військовослужбовців, потім зразки ОВТ.

Активну технічну розвідку також вели евакуаційні групи.

При підготовці операції виникли труднощі з технічним оснащенням евакуаційних груп. Пкво не мав достатньої кількості евакуаційних засобів, тому довелося терміново направляти 3 Центру та інших округів механіків-водіїв, такелажників і тягачі.

Особливість евакуації ОВТ полягала в наступному. Перед початком буксирування проводилися заходи: розмінування підходів до пошкоджених зразків ОВТ, збирання такелажних пристроїв, евакуація тіл загиблих членів екіпажів і десантів, підготовка ОВТ до евакуації. Підготовчі роботи 3 евакуації проводилися тільки силами евакуаційних груп.

Одним з найбільш істотних недоліків при виконанні заходів по евакуації була незахищеність тягачів динамічним захистом, що призводило до ураження об'єктів і загибелі екіпажів.

Рішення на ремонт ОВТ на маршрутах висування, як правило, не приймалися. Техніка яка вийшла з ладу евакуювалася в райони розміщення блокпостів ВВ МВС і далі на ЗППМ. Військові ремонтні органи 
здійснювали в основному ремонт базових шасі i нескладний ремонт озброєння i спеціального обладнання.

Порядок ремонту був наступним: ОВТ, що вийшли з ладу з технічних причин, в обсязі поточного ремонту відновлювалися в бойових порядках силами екіпажів і РВО підрозділів; ОВТ, які не ремонтувались

\section{Висновки}

На теперішній час уже восьмий рік на території Донецької та Луганської областей ведуться бойові дії 3 метою захисту територіальної цілісності та незалежності України, але незважаючи на наявний негативний досвід Тх3 бойових дій в Афганістані, Чечні, ЗС України стикнулись 3 тими самими проблемами у функціонуванні системи відновлення ОВТ. Як в попередніх війнах і збройних конфліктах зразки ОВТ, які знаходились на зберіганні подавались в зону проведення бойових дій без підготовки, що призводило до втрат ОВТ не пов'язаних 3 бойовими ушкодженнями, низький рівень

\section{Список використаних джерел}

1. Dachkovskyi, V. (2020). Formalization of problem and justification of the set of principles of construction of the system of restoration of weapons and military equipment.Journal of Scientific Papers "Social Development and Security», 10(4), 128-138. DOI: $10.33445 / s d s .2020 .10 .4 .12$

2. Стрельбіцький М.А. Математична модель функціонування системи відновлення озброєння та військової техніки / Стрельбіцький М.А., Дачковський В.О. // "Сучасні інформаційні технології у сфері безпеки та оборони", НУОУ. - 2020. - № 2(38) C. 87-94. DOI: 10.33099/23117249/2020-38-2-87-94

3. Коваленко О. А. Оцінювання можливостей ремонтно-відновлюваних органів 3 евакуації пошкоджених зразків озброєння та військової техніки / О. А. Коваленко // Сучасні інформаційні технології у сфері безпеки та оборони. - 2016. - № 1. - С. 55- силами підрозділів, евакуювалися на ЗППМ $[17,18]$.

Підсумком аналізу системи відновлення ОВТ, яка існувала в різні періоди $€$ сталі повторення В проблемних питаннях забезпечення військових частин та підрозділів, які вели бойові дії на різних театрах та не залежно від масштабів операції (бойових дій).

підготовки фахівців-ремонтників, неукомплектованість ремонтно-відновлювальних органів, відсутність засобів зв'язку та управління, відсутність завчасно створених запасних частин, тощо.

Таким чином, в подальшому на основі аналізу функціонування системи відновлення ОВТ у збройних конфліктах XX - XXI ст. та аналізу функціонування системи відновлення ОВТ В АТО необхідно провести кростемпоральне порівняння системи та визначити показники, які суттєво впливають на систему відновлення ОВТ з метою пошуку шляхів ії удосконалення.

58. URL: http://nbuv.gov.ua/UJRN/ sitsbo_2016_1_12

4. Коцюруба В. І. Методика оцінювання ефективності функціонування системи відновлення озброєння та військової техніки / В.І. Коцюруба, В.О. Дачковський// науковий журнал "Сучасні інформаційні технології у сфері безпеки та оборони", HyOУ. - 2020. - № 1(37) C. 5 - 14. DOI: 10.33099/2311-7249/2020-37-1-5-14

5. Шишанов, М. О. Методологічні основи структурного синтезу систем відновлення озброєння та військової техніки угруповання військ / М. О. Шишанов, М.М. Шевцов, О.Л. Чеченкова // Озброєння та військова техніка. - 2017. - № 3(15). С. 6670. DOI: 10.34169/2414-0651.2017.3(15).6670

6. Dachkovsky, V., \& Kondratiuk, I. (2020). Analysis of the fleet of military vehicles that will need to be restored by rolling stock 
maintenance and repair. Journal of Scientific Papers "Social Development and Security", 10(6), 216-228. DOI: $10.33445 /$ sds.2020.10.6.20

7. Павловський, О.В. Значення досвіду технічного забезпечення військ у Великій Вітчизняній війні для розвитку сучасної системи технічного забезпечення [Текст] / О. В. Павловський, О. О. Сисоєв // Наука і техніка ПС ЗС України: наук.-техн. журн./ ХУПС. - Х., 2010. - № 1 (3). - С. 202-205.

8. Карпенко А. С. Совершенствование технического обеспечения бронетанковых войск в операциях [Електронний ресурс] URL: http://www.rkka.ru/analys/btrepair/ main.htm

9. Dachkovskyi, V. (2019). Methodology of justification of tactical and technical requirements for movable means of repairing arms and military equipment. Journal of Scientific Papers "Social Development and Security", 9(6), 86-101. DOI: 10.33445/sds.2019.9.6.7

10. Баранов А., Баранов Ю., Іванський В., \& Малюк В. (2020). Аналіз факторів, які впливають на ефективність функціонування системи технічного обслуговування і ремонту машин інженерного озброєння. Збірник наукових праць Національної академії Державної прикордонної служби України. Серія: військові та технічні науки, 81(3), 281-290. DOI: $10.32453 / 3 . v 81 i 3.476$

11. Мейтин А.И., Турков А.Г. Тыловое обеспечение войск Советской Армии в Афганистане (1979-1989 гг.) журн. "Обозник" - Эл № ФС77-45222 - 2011 С. 1 [Електронний ресурc] DOI: http://www.oboznik.ru/?p=21917.

12. Dachkovskyi, V., Sampir, O., \& Horbachova,

Y. (2020). Methodical approach to evaluation of economic efficiency of repairing the weapons and military equipment. VUZF Review, 5(1), 22-30. DOI: 10.38188/25349228.20.1.03

13. Особливості технічного забезпечення російських військ у локальних війнах $\mathrm{i}$ збройних конфліктах ВІЙСьКОВА ДУМКА № 11/2008, C. 28-34.

14. Сисоєв, О. О. Проблеми, тенденції i перспективи розвитку системи технічного забезпечення військ (сил) у війнах і збройних конфліктах кінця XX і початку XXI століття [Текст] / О. О. СисоєВ. - К.: НАОУ, 2004. - 105 c.

15. Dachkovskyi, V. (2021). Methods of evaluation of efficiency of logistic operations. Journal of Scientific Papers "Social Development and Security», 11(1), 179-196. DOI: 10.33445/sds.2021.11.1.17

16. Kondratyuk, I. (2021). Analysis of the development of mobile maintenance and repair of military vehicles. Journal of Scientific Papers "Social Development and Security", 11(1), 52-69. DOI: 10.33445/sds.2021.11.1.6

17. Sampir, O. (2021). Improvement of the method of determining opportunities for technical exploration of damaged samples of weapons during combat. Journal of Scientific Papers "Social Development and Security", 11(2), 141-151. DOI: 10.33445/sds.2021.11.2.14

18. Гудима , В., Дачковський , В., \& Сампір , О. (2021). Методичний підхід до прогнозування потоку ремонтного фонду зразків озброєння та військової техніки. Збірник наукових праць $\Lambda^{\prime O} \mathrm{O}$. DOI: 10.36074/logos-26.02.2021.v1.40

\section{Анализ функционирования системы восстановления вооружения и военной техники}

\section{Ігорь Овчаренко * 1 А; Андрей Звонко ${ }^{2 \text { B; Антон Ткаченко }}{ }^{3}$ А; Александр Ярошенко 4 А}

Corresponding author: ${ }^{* 1}$ кандидат технических наук, доцент, профессор кафедры, e-mail: i-v-o@ukr.net, ORCID: 0000-0001-9066-0800 
${ }^{2}$ кандидат технических наук, доцент, доцент кафедры, e-mail: zvonko2008@ukr.net ORCID:0000-0002-7410-799X

${ }^{3}$ кандидат технических наук, старший научный сотрудник, начальник научного отдела, e-mail: i-v-o@ukr.net, ORCID: 0000-0002-1620-4206 ${ }^{4}$ старший преподаватель кафедры, e-mail: kss2014@ukr.net, ORCID: 0000-0001-9497-2262

А Национальный университет обороны Украины имени Ивана Черняховского, г. Киев, Украина

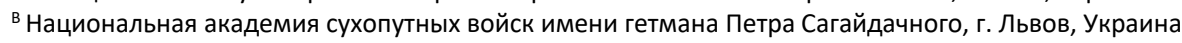

\begin{abstract}
Аннотация
Особенности ведения войн и вооруженных конфликтов указывают на то, что для обеспечения живучести военных формирований, принимающих участие в операциях (боевых действиях), одним из приоритетов является своевременный возврат к строю поврежденных образцов вооружения и военной техники. Успех выполнения задач при ведении вооруженного противостояния в значительной степени будет зависеть не только от огневых и ударных возможностей группировок войск (сил), но и от того, как быстро они смогут восстановить свою боеспособность в условиях влияния современных средств поражения.

Задача своевременного восстановления вооружения и военной техники, в ходе ведения операций (боевых действий) возлагается на ремонтно-восстановительные органы, от которых зависит уровень укомплектованности войск (сил) исправными образцами вооружения и военной техники. В статье проведен анализ условий и факторов, влияющих на систему восстановления вооружения и военной техники в широкомасштабных операциях во Второй мировой войне и в локальных войнах в Афганистане, в операции российских войск в первой чеченской кампании. Раскрыты основные проблемы, с которыми сталкивались ремонтно-восстановительные подразделения и части при восстановлении вооружения и военной техники в этих войнах и локальных вооруженных конфликтах с целью определения характерных проблемных вопросов, приводящих к снижению уровня боеспособности войск.
\end{abstract}

Ключевые слова: восстановление вооружения и военной техники, ремонтновосстановительные органы, ремонт, эвакуация, техническая разведка.

\title{
Analysis of functioning of the restoration system armament and military equipment
}

\section{Igor Ovcharenko * 1 A; Andrey Zvonko ${ }^{2}$ B; Anton Tkachenko ${ }^{3 \mathrm{~A}}$; Alexander Yaroshenko $4 \mathrm{~A}$}

Corresponding author: * ${ }^{1}$ Candidate of Technical Sciences, Professor of the Department, e-mail: i-v-o@ukr.net, ORCID: 0000-0001-9066-0800

${ }^{2}$ Candidate of Technical Sciences, assistant Professor of the Department, e-mail: zvonko2008@ukr.net, ORCID: 0000-0002-7410-799X

${ }^{3}$ Candidate of Technical Sciences, Senior Scientist, Head of the Department, e-mail: i-v-o@ukr.net, ORCID: 0000-0002-1620-4206

${ }^{4}$ Senior lecturer, e-mail: kss2014@ukr.net, ORCID: 0000-0001-9497-2262

A National Defence University of Ukraine named after Ivan Cherniachovskyi, Kyiv, Ukraine

${ }^{B}$ Hetman Petro Sahaidachnyi National Army Academy, Lviv, Ukraine

\begin{abstract}
The features of wars and armed conflicts indicate that timely return to the repair of damaged weapons and military equipment is one of the priorities to ensure the survivability of military formations participating in operations (combat operations). The success of the tasks of armed confrontation will largely depend not only on the fire and shock capabilities of the forces (forces), but also on how quickly they will be able to restore their combat capability under the influence of modern means of defeat. The task of timely restoration of armaments and military equipment, in the course of conducting operations (combat operations), relies on repair and restoration agencies, on which the level of staffing of troops (forces) depends on the working patterns of armaments and military equipment.

The article analyzes the conditions and factors that influenced the system for the restoration of armaments and military equipment in large-scale operations in the Second World War and local wars in Afghanistan, in the operation of Russian troops in the First Chechen campaign. The main
\end{abstract}


problems faced by repair and restoration units and parts during the restoration of armaments and military equipment in these wars and local armed conflicts were revealed. The research was conducted with the purpose of identifying the characteristic problem issues that arose in the wars and armed conflicts of the 20th - 21st centuries. and which arise at present, which leads to a decrease in the level of combat capability of the troops. The main characteristic of the use of repair and restoration units that were used is that they are all followers of the Soviet system for providing troops (forces) and have some principles (approaches) to accomplishing tasks.

Keywords: restoration of armaments and military equipment, repair and restoration bodies, repair, evacuation, technical reconnaissance.

\section{References}

1. Dachkovskyi, V. (2020). Formalization of problem and justification of the set of principles of construction of the system of restoration of weapons and military equipment. Journal of Scientific Papers "Social Development and Security", 10(4), 128-138. DOI: $10.33445 / s d s .2020 .10 .4 .12$

2. Strelbitsky, M. A., Dachkovsky, V. O. (2020). Mathematical model of functioning of the system of restoration of armaments and military equipment. Modern information technologies in the field of security and defense, № 2 (38) P. 87-94. DOI: 10.33099/2311-7249/2020-38-2-87-94

3. Kovalenko, O. A. (2016). Estimation of possibilities of repair and restoration bodies for evacuation of damaged samples of armament and military equipment. Modern information technologies in the field of security and defense. № 1. P. 55-58. Access mode: http: //nbuv.gov.ua/UJRN/sitsbo_ 2016_1_12

4. Kotsyuruba, V. I., Dachkovsky, B. O. (2020). Methods for evaluating the effectiveness of the system of restoration of armaments and military equipment. Modern information technologies in the field of security and defense, № 1 (37) P. 5 - 14. DOI: 10.33099/2311-7249/2020-37-1-5-14

5. Shishanov, M.O., Shevtsov, M. M., Chechenkova, O. L. (2017). Methodological bases of structural synthesis of systems of restoration of armament and military equipment of grouping of troops. Weapons and military equipment. № 3 (15). Pp. 66-70. DOI: 10.34169/2414-0651.2017.3(15).66-70

6. Dachkovsky, V., \& Kondratiuk, I. (2020). Analysis of the fleet of military vehicles that will need to be restored by rolling stock maintenance and repair. Journal of Scientific Papers "Social Development and Security", 10(6), 216-228. DOI: 10.33445/sds.2020.10.6.20

7. Pavlovsky, O.V., Sysoev, O.O. (2010). The value of the experience of technical support of troops in the Great Patriotic War for the development of the modern system of technical support. Nauka i tekhnika PS ZS Ukrainy: nauk.-tehn. Journal № 1 (3). P. 202205.

8. Karpenko, A.S. Improving the technical support of armored troops in operations [Electronic resource]. Mode of access : http://www.rkka.ru/analys/btrepair/main.ht $m$

9. Dachkovskyi, V. (2019). Methodology of justification of tactical and technical requirements for movable means of repairing arms and military equipment. Journal of Scientific Papers "Social Development and Security», 9(6), 86-101. DOI: 10.33445/sds.2019.9.6.7

10. Baranov A., Baranov Y., Ivansky V., \& Malyuk V. (2020). Analysis of factors that affect the efficiency of the system of maintenance and repair of engineering weapons. Collection of scientific works of the National Academy of the State Border Guard Service of Ukraine. Series: Military and Technical Sciences, 81 (3), 281-290. DOI: 10.32453/3.v81i3.476

11. Meitin Al, Turkov AG Logistics of the Soviet Army in Afghanistan (1979-1989) magazine. Эл № ФС77-45222, 2011, С. 1 Mode of access : http://www.oboznik.ru/?p=21917

12. Dachkovskyi, V., Sampir, O., \& Horbachova, Y. (2020). Methodical approach to evaluation 
of economic efficiency of repairing the weapons and military equipment. VUZF Review, 5(1), 22-30. DOI: 10.38188/25349228.20.1.03

13. Features of technical support of Russian troops in local wars and armed conflicts MILITARY THOUGHT № 11/2008, p. 28-34.

14. Sysoev, O. O. Problems, tendencies and prospects of development of the system of technical support of troops (forces) in wars and armed conflicts of the end of the $X X$ and the beginning of the XXI century [Text] Kyiv: NDUU, 2004. 105 p.

15. Dachkovskyi, V. (2021). Methods of evaluation of efficiency of logistic operations. Journal of Scientific Papers "Social Development and Security», 11(1), 179-196. DOI: 10.33445/sds.2021.11.1.17
16. Kondratyuk, I. (2021). Analysis of the development of mobile maintenance and repair of military vehicles. Journal of Scientific Papers "Social Development and Security», 11(1), 52-69. DOI: 10.33445/sds.2021.11.1.6

17. Sampir, O. (2021). Improvement of the method of determining opportunities for technical exploration of damaged samples of weapons during combat. Journal of Scientific Papers "Social Development and Security», 11(2), 141-151. DOI: 10.33445/sds.2021.11.2.14

18. Hudyma, V., Dachkovsky, V., \& Sampir, O. (2021). Methodical approach to forecasting the flow of the repair fund of samples of weapons and military equipment. Collection

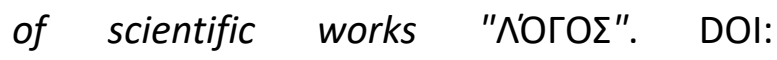
10.36074/logos-26.02.2021.v1.40 